Contents available at PubMed

Rev Inves Clin. 2018;70:158-63

\title{
BORRELIA INFECTION IN LATIN AMERICA
}

\author{
Alejandro Robles ${ }^{1}$, James Fong ${ }^{2}$ and Jorge Cervantes $2,3 *$ \\ ${ }^{1}$ Department of Internal Medicine, ${ }^{2}$ Paul L. Foster School of Medicine and ${ }^{3}$ Department of Medical Education, \\ Texas Tech University Health Sciences Center, El Paso, TX, USA
}

\begin{abstract}
Lyme disease (LD) is a multisystemic inflammatory disease caused by pathogenic spirochetes, belonging to the genospecies complex Borrelia burgdorferi sensu lato (B.b.s.l.). Around the world, distinct species of Ixodes tick vectors transmit different species of Borrelia. Despite the rising recognition and occurrence of tick-borne disease in Latin America, serology has proven to be inconclusive in detecting suspected LD cases. Recently, new B.b.s.l. strains or new related species have been described in Brazil, Uruguay, and Chile. This could explain the lack of confirmatory tests, such as indeterminate Western blots (WBs) and polymerase chain reactions, in detecting suspected LD cases in this region of the world. Future studies will need to determine the extension of novel B.b.s.l. species infections in ticks, reservoirs, and humans in Latin America. The existence of these new Borrelia genomic species should prompt the development of innovative diagnostic and clinical approaches. (REV INVES CLIN. 2018;70:158-63)
\end{abstract}

Key words: Lyme disease. Borrelia. Latin America.

\section{LYME DISEASE (LD) - GLOBAL DISTRIBUTION}

LD is the most common vector-borne illness in the United States, and a major zoonosis in Europe and China ${ }^{1,2}$. It is currently the zoonosis transmitted by arthropods with the highest incidence rate and prevalence in the United States, Europe, and Asia. LD is a multisystemic inflammatory disease caused by pathogenic spirochetes of the Borrelia burgdorferi sensu lato (B.b.s.l.) complex.

LD was first described nearly 40 years ago after an investigation of a cluster of cases originally thought to be juvenile rheumatoid arthritis in children living in Connecticut ${ }^{3}$. However, there is evidence to suggest

\author{
Corresponding author: \\ * Jorge Cervantes \\ Department of Medical Education \\ Paul L. Foster School of Medicine \\ Texas Tech University Health Sciences Center \\ 5001 El Paso Dr., El Paso, TX, 79905, USA \\ E-mail: jorge.cervantes@ttuhsc.edu
}

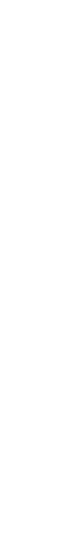

Received for publication: 16-02-2018 Approved for publication: 21-03-2018 doi: $10.24875 /$ RIC.18002509 
Figure 1. Presence of Borrelia burgdorferi sensu lato in ticks from South America.

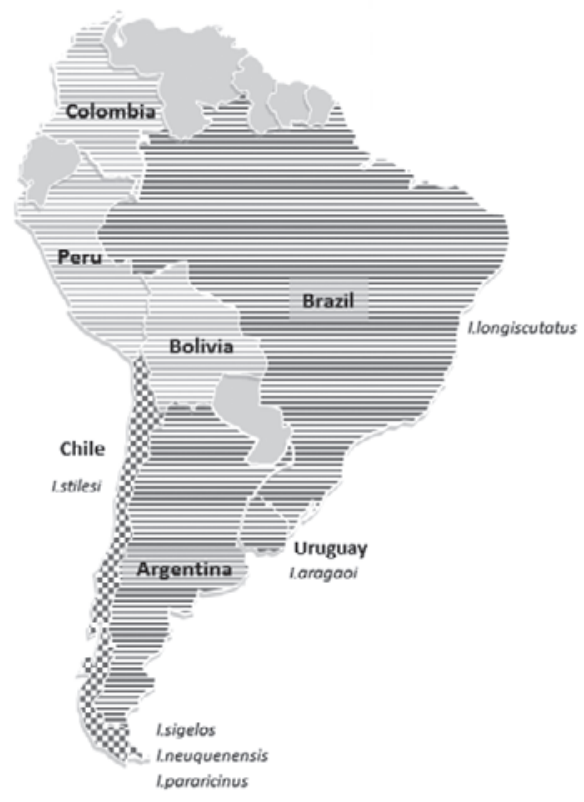

I. pararicinus

I. pararicinus infected with B.b.s.l.

QI. ricinus complex ticks infected with $B$. chilensis that B.b. has affected humans for thousands of years. The Tyrolean Iceman, or Ötzi, a 5300-year-old mummy discovered in 1991 in the Ötztal Alps, has become one of the most studied cadavers in science. A wholegenome study was performed in 2010 yielding, among other things, sequences corresponding to approximately $60 \%$ of the genome of B.b., making him the earliest known human to be infected by the pathogen that causes $\mathrm{LD}^{4}$. The finding of multiple simple linear tattoos at or near traditional acupuncture points, along with the presence of B.b. DNA makes a compelling case that this individual was possibly affected by LD $^{5}$.

Although originally described in North America, borreliosis has also been described in other parts of the world such as Asia, Russia, North Africa, and Europe ${ }^{2,6}$, and possibly Oceania ${ }^{7}$ and South America ${ }^{8}$. The spirochetes are transmitted to humans when accidentally bitten by ticks infected with the pathogen.

\section{VECTORS AND BORRELIA EVOLUTION}

The species of Borrelia associated with LD are grouped in a bacterial genospecies complex called B.b.s.l., which includes $B$. burgdorferi sensu stricto
(B.b.s.s) $)^{9}$. In Eurasia, other five genospecies of the B.b.s.l. complex are associated with LD: B.b., Borrelia afzelii, Borrelia garinii, Borrelia bavariensis, and Borrelia spielmanii ${ }^{9}, 10$. These species, transmitted through geographically diverse tick vectors, are associated with different clinical presentations of the disease ${ }^{11}$. This Borrelia and tick specificity also holds true for Borrelia that causes relapsing fever ${ }^{12}$ and has been confirmed in several parts around the world, including Russia and Asia ${ }^{13-15}$.

In the United States, the LD spirochete lives in nature in an enzootic cycle that includes mainly ticks of the genus Ixodes ${ }^{2}$. Ixodes scapularis was initially implicated as a vector in the southeastern United States and has expanded throughout the decades $^{16,17}$. Currently, in North America, B.b. is mostly transmitted by $I$. scapularis ticks in northeastern and Midwestern United States and South Canada, and by Ixodes pacificus in the West Coast of the United States and Canada. In Eurasia, the different B.b.s.l. genospecies use Ixodes ricinus (in Europe) and Ixodes persulcatus (in Asia) for transmission ${ }^{10}$. The rodent Peromyscus leucopus is the main reservoir of the disease, and the white-tailed deer (Odocoileus virginianus) serves as the tick's primary host. 
The Neotropical tick Ixodes pararicinus is distributed along Argentina, Colombia, and Uruguay, but it is also probably established in Bolivia, Brazil, Chile, and Peru ${ }^{18}$ (Fig. 1). Bird migration appears to help in the dispersion of infected ticks across countries ${ }^{19}$. Most adult ticks of this species have been found on introduced domestic artiodactyls, although Neotropical deer species must have been the ancestral host ${ }^{20}$. Larvae and nymphs of $I$. pararicinus have also been found on sigmodontine rodents and passeriform birds ${ }^{18}$. Birds from that region also harbor ticks other than the family Ixodidae such as Haemaphysalis juxtakochi and Amblyomma species ${ }^{21}$. There are several species of Amblyomma in the South American region, some of them parasitizing humans ${ }^{22}$. Although I. pararicinus is a member of the $I$. ricinus complex, which contains the main vectors of B.b.s.l., there are few studies concerning its potential for pathogen transmission in South America23,24.

Several species of ticks of the genera Ixodes (I. ricinus, I. uriae, I. chilensis, I. taglei, I. stilesie, I. sigelos, I. auritulus, and I. cornuae) and Amblyomma (A. tigrinum and $A$. maculatum) have been described in Chile ${ }^{25,26}$, Peru ${ }^{27-29}$, and Argentina ${ }^{23}$. In the latter, two out of 12 I. pararicinus ticks were infected with B.b.s.l. ${ }^{23}$. Birds, several rodent species, and lagomorphs, like the hare, have been proposed as reservoirs ${ }^{25,26}$. A study aiming on detecting the presence of B.b.s.s. by polymerase chain reaction (PCR) for the ospA gene in ticks collected from wild rodents yielded negative results ${ }^{26}$. These results meant that the ticks were not colonized with B.b.s.s., although the presence of other species within the B.b.s.l. complex could not be ruled out.

\section{BORRELIOSIS IN LATIN AMERICA}

In Latin America, a national-based serosurvey in Mexico on 2980 individuals yielded a seroprevalence of $0.3 \%$ by Western blot (WB) ${ }^{30}$. A second study by the same group, found a seroprevalence of $3.43 \%$ in Mexico City and of $6.2 \%$ in the Northeast region of the country ${ }^{31}$. A later surveillance study in 72 Mexican children with clinical suspicion of LD yielded a confirmatory serology by WB in 20 of them, to three species of B.b.s.l. (B.b.s.s., B. afzelii, and B. garinii) ${ }^{32} .14$ of these 20 seropositive cases rendered a positive PCR for fla and ospA genes in either skin, cerebrospinal fluid (CSF), or synovial fluid ${ }^{32}$. A case of LD with positive ELISA and confirmatory WB results was reported in Honduras in $2004^{33}$. In this country, a report by the U.S. Special Operations Forces on stray cats showed a prevalence of positive serology for B.b. of $25 \%^{34}$. Although B.b. was not detected in a study on dogs and cats undergoing sterilization in Costa Rica ${ }^{35}$, two cases from this country with diagnosis based on positive IgM against B.b. have been published ${ }^{36,37}$. In Cuba, a serological survey using ELISA and WB rendered a seroprevalence of $2 \%$ to B.b.s.s. ${ }^{38}$. Serological diagnostic tests for LD have variable sensitivity and specificity, and a two-tiered serology protocol typically of an ELISA followed by a WB to detect serum $\lg M$ or $\lg G$ antibodies to B.b., is the only validated diagnostic approach for LD diagnosis ${ }^{39}$.

In South America, tick-borne disease recognition and occurrence have been rising, due to awareness of LD, with an active search for the presence of infection by B.b. in ticks and humans. In Brazil, a Lyme-like disease known as Baggio-Yoshinari syndrome has been described since $1993^{40}$. This disease appears to be caused by microorganisms that may ${ }^{41}$ or may not belong to the B.b.s.l. complex, transmitted by ticks of the Amblyomma and Rhipicephalus genera ${ }^{42}$. The presence of spirochetes has been detected in blood of Brazilian patients with LD-like syndrome $\mathrm{e}^{42}$, and in skin from patients with erythema migrans $(E M)^{43}$. A study in patients with different skin disorders (distinct of LD) from Brazil showed that more than $7 \%$ of them had a positive ELISA, and over $50 \%$ of these patients had a positive $W^{44}$. Six cases of $L D$, presenting with EM, with positive ELISA serology, and one EM with direct detection of spirochetes ${ }^{45}$, were reported between 1992 and 1999 in Peru. Cases of EM have already been documented in Peru previously ${ }^{46}$.

A retrospective serum survey in Peru performed on 216 individuals, found 4 (2\%) to be positive for B.b. antibodies by ELISA ${ }^{28}$. The presence of antibodies against B.b. using ELISA was found in $10 \%$ of 232 otherwise healthy subjects in Northern Peru ${ }^{27}$. In Colombia, the seroprevalence among farmers was $4.6 \% 47$ and $3 \%$ in Bolivia ${ }^{48}$.

Two cases of Parry-Romberg syndrome (PRS) with positive IgM serology against B.b. were reported from $\mathrm{Peru}^{49}$. PRS or progressive hemifacial atrophy is a rare entity of unknown etiology, characterized by unilateral atrophy of the skin, subcutaneous tissue, and the 
Figure 2. Lyme disease in Latin America.

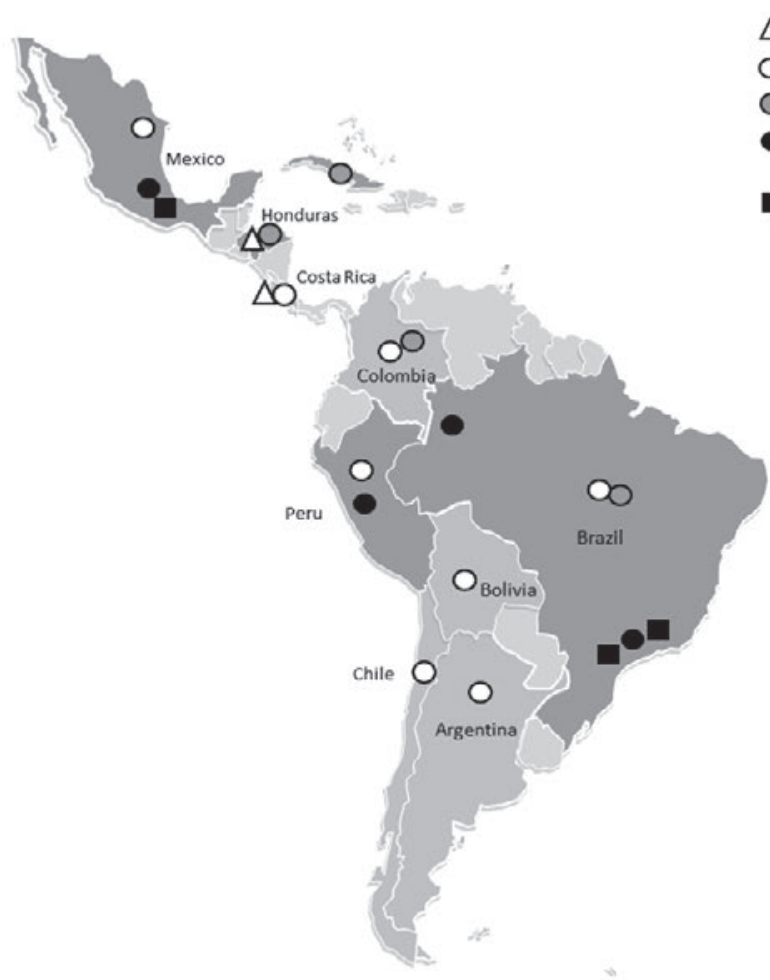

$\triangle$ Positive ELISA (mammalians)

O Positive ELISA (humans)

Confirmed serology (WB)

- Positive culture positive / Spirochete microscopy

- PCR positive

underlying bony structures. Although no definite association between PRS and LD has been established, yet several cases have demonstrated a coincident occurrence with LD. In some instances, an IgM and positive culture of Borrelia have been found ${ }^{49-51}$.

In a seroepidemiologic investigation in farm workers from Argentina with arthritis symptoms, approximately $10 \%$ tested positive for lgM and/or $\operatorname{lgG}^{52}$.

The first report of LD in South America came from Chile in the form of a study of 25 patients with neurological disease of unknown etiology. The study was based on clinical and serological diagnosis by ELISA, with no confirmation by isolation ${ }^{53}$. A later study from the same country on 118 patients with signs or symptoms suggestive of LD, added a WB to the ELISA screening. All sera and CSF were negative for confirmatory WB analysis ${ }^{54}$. This led toward the conclusion that there was not enough evidence to confirm the presence of the agent in the country, but from this study emerged the hypothesis of the possible existence of a local strain of Borrelia, antigenically different or with different epidemiological profiles from the one investigated in the study ${ }^{54}$. In Colombia, a study on 20 serum samples from patients with signs of Lyme borreliosis showed that only four fulfilled the CDC WB criteria ${ }^{55}$. A similar situation occurred in Brazil, where despite positive IgM serology, only one of the cases gave a positive $\mathrm{WB}$, and it was undetermined in another ${ }^{56}$. Studies using a battery of primers to detect B.b. by PCR in Brazil, have failed, except when targeting the gene $f l g E^{8}$. This suggested again that a different strain of B.b. or a different species of B.b.s.l. may be the causative agent. This proved to be the case, when testing serum samples from farmers in Brazil using a nested PCR revealed the presence of B. garinii and B.b.s.s. ${ }^{41}$. A graphic summary of all the discussed reports is depicted in figure 2 .

Although serology is not conclusive evidence of the presence of Lyme borreliosis in South America, it represents indirect evidence of exposure to Borrelia, as some cross-reactivity with other species, such as the Borrelia species associated with relapsing fever, may exist ${ }^{57-60}$. 


\section{NEW BORRELIA SPECIES}

In Uruguay, analysis of infection in ticks of the I. ricinus complex collected from deer, cattle, or vegetation showed that these were infected by possibly two new B.b.s.l. genospecies, one associated with $B$. bissettiae and the other phylogenetically closest to $B$. americana ${ }^{61}$.

Although initial studies could not confirm the existence of LD in Chile, they prompt the question that a local species of Borrelia could be antigenically different compared to North American strains and thus did not render a positive $\mathrm{WB}^{54}$. A PCR-based study for the ospA gene of B.b.s.s. in ticks collected from wild rodents and cervidae in the Southern region of Chile, failed to detect the presence of B.b. ${ }^{26}$. Although the elements required for the enzootic cycle of B.b., such as the reservoir and vector, are present in Chile, their direct detection in Chilean ticks using nested PCR was negative. A new Borrelia species, named B. chilensis, has been found in $I$. stilesi ticks collected from environmental vegetation, deer, and rodents from that region ${ }^{62-64}$. Given the genetic differences with the American B.b. B31 strain ${ }^{62}$, it is possible that the presence of new species could explain the lack of confirmatory tests, like WB, in previous suspected LD cases in South America. In some of the reports, there is a lack of details on the specificity of the ELISA utilized. It has been shown that even antibodies against serotypic variants of Borrelia species on a regional scale cannot be detected by commercial serology test kits ${ }^{65}$.

In Southeastern US, Borrelia species other than B.b., such as $B$. bissettiae, have been isolated from patients with symptoms not typical of $L^{66}$. Future studies will need to determine the prevalence of Borrelia infection (B.b.s.l. and B. chilensis) in ticks in this part of the world.

It appears that $B$. chilensis and possible new strains or new related species are extended throughout South America ${ }^{67}$. Utilizing a battery of PCR methods targeting the gene flagellin ( $f l a$ ) and the rrfA-rrlB intergenic spacer region, it has been shown that I. sigelos, I. neuquenensis, and $I$. pararicinus ticks are infected with B.b.s.l. related to $B$. chilensis in the Patagonian 68 and northwestern regions of Argentina. (Fig. 1)23,24,69.

New species of B.b.s.l., like the one termed Borrelia sp. haplotype Pampa, have been described infecting $I$. longiscutatus ticks in Brazil70. The clinical significance of these new Borrelia genomic species remains to be elucidated.

Although the initial reports have been scattered, sometimes lacking detailed information on serological testing, the inconsistent confirmatory results could be explained by the presence of new species of B.b.s.l. in these countries. Future studies will need to determine the extension of new B.b.s.l. species infections in ticks, reservoirs, and humans in Latin America. The existence of these new Borrelia genomic species should prompt the development of novel diagnostic and clinical approaches.

\section{REFERENCES}

1. Mead PS. Epidemiology of lyme disease. Infect Dis Clin North Am. 2015;29:187-210.

2. Schotthoefer AM, Frost HM. Ecology and epidemiology of lyme borreliosis. Clin Lab Med. 2015;35:723-43.

3. Borchers AT, Keen CL, Huntley AC, Gershwin ME. Lyme disease: a rigorous review of diagnostic criteria and treatment. J Autoimmun. 2015;57:82-115.

4. Keller A, Graefen A, Ball M, et al. New insights into the tyrolean iceman's origin and phenotype as inferred by whole-genome sequencing. Nat Commun. 2012;3:698.

5. Deter-Wolf A, Robitaille B, Krutak L, Galliot S. The world's oldest tattoos. J Archaeol Sci Rep. 2016;5:19-24.

6. Stone BL, Tourand Y, Brissette CA. Brave new worlds: the expanding universe of lyme disease. Vector Borne Zoonotic Dis. 2017;17:619-29.

7. Collignon PJ, Lum GD, Robson JM. Does lyme disease exist in Australia? Med J Aust. 2016;205:413-7.

8. Mantovani E, Marangoni RG, Gauditano G, Bonoldi VL, Yoshinari $\mathrm{NH}$. Amplification of the flgE gene provides evidence for the existence of a Brazilian borreliosis. Rev Inst Med Trop Sao Paulo. 2012;54:153-7.

9. Margos G, Vollmer SA, Ogden NH, Fish D. Population genetics, taxonomy, phylogeny and evolution of Borrelia burgdorferi sensu lato. Infect Genet Evol. 2011;11:1545-63.

10. Mechai S, Margos G, Feil EJ, et al. Evidence for host-genotype associations of Borrelia burgdorferi sensu stricto. PLoS One. 2016;11:e0149345.

11. Kurtenbach K, Hanincová K, Tsao Jl, et al. Fundamental processes in the evolutionary ecology of Iyme borreliosis. Nat Rev Microbiol. 2006;4:660-9.

12. Padgett $K$, Bonilla $D, K j e m t r u p ~ A$, et al. Large scale spatial risk and comparative prevalence of Borrelia miyamotoi and Borrelia burgdorferi sensu lato in Ixodes pacificus. PLoS One. 2014; 9:e110853.

13. Masuzawa T. Terrestrial distribution of the lyme borreliosis agent Borrelia burgdorferi sensu lato in East Asia.Jpn J Infect Dis. 2004:57:229-35.

14. Liu S, Yuan C, Cui YF, et al. Investigation of Borrelia spp. In ticks (Acari: ixodidae) at the border crossings between China and Russia in Heilongjiang province, China. Asian Pac J Trop Med. 2012;5:459-64.

15. Ni XB, Jia N, Jiang BG, et al. Lyme borreliosis caused by diverse genospecies of Borrelia burgdorferi sensu lato in Northeastern China. Clin Microbiol Infect. 2014;20:808-14.

16. Khatchikian CE, Prusinski M, Stone M, et al. Geographical and environmental factors driving the increase in the Lyme disease vector Ixodes scapularis. Ecosphere. 2012;3:pii art85.

17. Kilpatrick AM, Dobson AD, Levi T, et al. Lyme disease ecology in a changing world: consensus, uncertainty and critical gaps for improving control. Philos Trans R Soc Lond B Biol Sci. 2017;372.

18. Venzal JM, Estrada-Peña A, Barros-Battesti DM, Onofrio VC, Beldoménico PM. Ixodes (Ixodes) pararicinus keirans \&amp; clifford, 1985 (Acari: ixodidae): description of the immature stages, distribution, hosts and medical/veterinary importance. Syst Parasitol. 2005;60:225-34. 
19. Scott JD, Lee MK, Fernando K, et al. Detection of lyme disease spirochete, Borrelia burgdorferi sensu lato, including three novel genotypes in ticks (Acari: ixodidae) collected from songbirds (Passeriformes) across Canada. J Vector Ecol. 2010;35:124-39.

20. Venzal JM, Castro O, Cabrera PA, de Souza CG, Guglielmone AA. Las garrapats de Uruguay: especies, hospedadores, distribucion e importancia sanitaria. Vet (Montevideo). 2003;38:17-28.

21. Venzal JM, Félix ML, Olmos A, Mangold AJ, Guglielmone AA. A collection of ticks (Ixodidae) from wild birds in uruguay. Exp Appl Acarol. 2005;36:325-31.

22. Guglielmone AA, Beati L, Barros-Battesti DM, et al. Ticks (IXodidae) on humans in South America. Exp Appl Acarol. 2006; 40:83-100.

23. Nava S, Barbieri AM, Maya L, et al. Borrelia infection in Ixodes pararicinus ticks (Acari: ixodidae) from northwestern argentina. Acta Trop. 2014;139:1-4

24. Saracho Bottero MN, Sebastian PS, Carvalho LA, et al. Presence of Borrelia in different populations of Ixodes pararicinus from northwestern argentina. Ticks Tick Borne Dis. 2017;8:488-93.

25. Gonzalez-Acuna D, Venzal JM, Guglielmone AA. Nuevos hospedadores y localidades de Ixodes sigelos e Ixodes auritulus (Acari: ixodidae) en Chile. Gayana. 2004;68:108-11.

26. Osorio G. Search for the spirochete Borrelia burgdorferi sensu lato by polymerase chain reaction in wild chilean ticks. Rev Med Chil. 2001;129:270-6.

27. Glenny M, Mendoza L, Falconi E. Detection of antibodies to Borrelia burgdorferi and identification of ixodid ticks in Piura and Amazonas, Peru. Rev Peru Med Exp Salud Publica. 2004;20:23-7.

28. Need JT, Escamilla J. Lyme disease in South America? J Infect Dis. 1991;163:681-2.

29. Mendoza-Uribe L, Chavez-Chorocco J. Ampliacion geografica de siete especies de Amblyomma (Acari: ixodidae) y primer reporte de A. Oblongoguttatum Koch, 1844 para Peru. Rev Peru Entomol. 2004;44:66-72.

30. Gordillo G, Torres J, Solorzano F, et al. Serologic evidences suggesting the presence of Borrelia burgdorferi infection in Mexico. Arch Med Res. 1999;30:64-8

31. Gordillo-Pérez G, Torres J, Solórzano-Santos F, Garduño-Baustista V, Tapia-Conyer R, Muñoz O. Estudio seroepidemiológico de borreliosis de Lyme en la Ciudad de México y el noreste de la República Mexicana. Salud Publica Mex. 2003;45:351-5.

32. Gordillo-Pérez G, Solórzano-Santos F. Lyme disease: experience in Mexican children. Bol Med Hosp Infant Mex. 2010; 67:164-76.

33. Su H. Lyme disease. A case report. Rev Med Hond. 2004;72:193-7.

34. McCown M, Grzeszak B. Zoonotic and infectious disease surveillance in central America: honduran feral cats positive for toxoplasma, trypanosoma, leishmania, rickettsia, and lyme disease. J Spec Oper Med. 2010;10:41-3.

35. Scorza AV, Duncan C, Miles L, Lappin MR. Prevalence of selected zoonotic and vector-borne agents in dogs and cats in Costa rica. Vet Parasitol. 2011;183:178-83

36. Boza-Cordero R. Lyme disease in Costa Rica, a case report. Acta Med Costarric. 2010;53:34-6.

37. Villalobos-Zuniga MA, Somogyi T. Acute Lyme disease in Costa Rica: description of the first autochthonous case. Acta Med Costarric. 2012;54:55-8

38. Rodríguez I, Fernández C, Sánchez L, et al. Prevalence of antibodies to Borrelia burgdorferi sensu stricto in humans from a cuban village. Braz J Infect Dis. 2012;16:82-5.

39. Waddell LA, Greig J, Mascarenhas M, et al. The accuracy of diagnostic tests for lyme disease in humans, A systematic review and meta-analysis of North American research. PLoS One. 2016;11:e0168613.

40. Yoshinari NH, Oyafuso LK, Monteiro FG, et al. Lyme disease. Report of a case observed in Brazil. Rev Hosp Clin Fac Med Sao Paulo. 1993;48:170-4.

41. Goncalves DD, Moura RA, Nunes M, et al. Borrelia burgdorferi sensu lato in humans in a rural area of Parana State, Brazil. Braz ] Microbiol. 2015;46:571-5.

42. Mantovani E, Costa IP, Gauditano G, et al. Description of lyme disease-like syndrome in Brazil. Is it a new tick borne disease or lyme disease variation? Braz J Med Biol Res. 2007;40:443-56.

43. Talhari S, de Souza Santos MN, Talhari C, et al. Borrelia burgdorferi "sensu lato" in Brazil: occurrence confirmed by immunohistochemistry and focus floating microscopy. Acta Trop. 2010; 115:200-4.

44. Santos M, Ribeiro-Rodrigues R, Lobo R, Talhari S. Antibody reactivity to Borrelia burgdorferi sensu stricto antigens in patients from the Brazilian Amazon region with skin diseases not related to Lyme disease. Int J Dermatol. 2010;49:552-6.
45. Castillo RW, Castillo FW. Borreliosis de Lyme encel Perú. Rev Farmacol Terap (Lima). 1999;6:72-4.

46. Romero O, Galarza C, Rueda M. Eritema crónico migrans. Dermatol Peru. 1996;6:???

47. Miranda J, Mattar S, Perdomo K, Palencia L. Seroprevalence of lyme borreliosis in workers from Cordoba, Colombia. Rev Salud Publica (Bogota). 2009;11:480-9.

48. Briancon C. Lyme disease in Tarija, Bolivia. Rev Soc Bol Ped. 2003;42:166-9.

49. Manyari CG, Gutierrez E, Munoz R, et al. Parry romberg syndrome. Dermatol Peru. 2006;16:151-4.

50. Sahin MT, Bariş S, Karaman A. Parry-romberg syndrome: a possible association with borreliosis. J Eur Acad Dermatol Venereol. 2004;18:204-7.

51. Baskan EB, Kaçar SD, Turan A, et al. Parry-romberg syndrome associated with borreliosis: could photochemotherapy halt the progression of the disease? Photodermatol Photoimmunol Photomed. 2006;22:259-61.

52. Stanchi NO, Balague LJ. Lyme disease: antibodies against Borrelia burgdorferi in farm workers in Argentina. Rev Saude Publica. 1993;27:305-7.

53. Barahona JS, Miranda MT, Lobo JC. Enfermedad de lyme en chile. Rev Med Chil. 1989;117:946-7.

54. Neira O, Cerda C, Alvarado MA, et al. Lyme disease in chile. Prevalence study in selected groups. Rev Med Chil. 1996; 124:537-44.

55. Palacios R, Osorio LE, Giraldo LE, et al. Positive igG western blot for Borrelia burgdorferi in colombia. Mem Inst Oswaldo Cruz. 1999:94:499-503.

56. Carranza-Tamayo CO, Costa JN, Bastos WM. Lyme disease in the state of tocantins, Brazil: Report of the first cases. Braz J Infect Dis. 2012;16:586-9.

57. Barka NE, Agopian MS, Peter JB. False-positive IgM antibodies to Borrelia burgdorferi in indirect ELISA as a result of IgM rheumatoid factor. J Infect Dis. 1990;161:1312.

58. Magnarelli LA, Miller JN, Anderson JF, Riviere GR. Cross-reactivity of nonspecific treponemal antibody in serologic tests for lyme disease. J Clin Microbiol. 1990;28:1276-9.

59. Raoult D, Hechemy KE, Baranton G. Cross-reaction with Borrelia burgdorferi antigen of sera from patients with human immunodeficiency virus infection, syphilis, and leptospirosis. J Clin Microbiol. 1989;27:2152-5.

60. Ciceroni L, Bartoloni A, Guglielmetti P, et al. Prevalence of antibodies to Borrelia burgdorferi, Borrelia parkeri and Borrelia turicatae in human settlements of the Cordillera Province, Bolivia. J Trop Med Hyg. 1994;97:13-7.

61. Barbieri AM, Venzal JM, Marcili A, et al. Borrelia burgdorferi sensu lato infecting ticks of the Ixodes ricinus complex in uruguay: First report for the southern hemisphere. Vector Borne Zoonotic Dis. 2013:13:147-53.

62. Ivanova LB, Tomova A, González-Acuña D, et al. Borrelia chilensis, a new member of the Borrelia burgdorferi sensu lato complex that extends the range of this genospecies in the southern hemisphere. Environ Microbiol. 2014;16:1069-80.

63. Huang W, Ojaimi C, Fallon JT, et al. Genome sequence of Borrelia chilensis VA1, a South American member of the Lyme borreliosis group. Genome Announc. 2015;3:e01535-14.

64. Verdugo $C$, Jiménez $O$, Hernández $C$, et al. Infection with Borrelia chilensis in Ixodes stilesi ticks collected from pudu puda deer. Ticks Tick Borne Dis. 2017;8:733-40.

65. Cook MJ, Puri BK. Commercial test kits for detection of lyme borreliosis: a meta-analysis of test accuracy. Int J Gen Med. 2016;9:427-40.

66. Rudenko N, Golovchenko M, Vancova M, Clark K, Grubhoffer L, Oliver JH Jr. Isolation of live Borrelia burgdorferi sensu lato spirochaetes from patients with undefined disorders and symptoms not typical for Lyme borreliosis. Clin Microbiol Infect. 2016:22:267, e9-15.

67. Basile RC, Yoshinari NH, Mantovani E, et al. Brazilian borreliosis with special emphasis on humans and horses. Braz ] Microbiol. 2017:48:167-72

68. Sebastian PS, Bottero MN, Carvalho L, et al. Borrelia burgdorferi sensu lato in Ixodes cf. Neuquenensis and Ixodes sigelos ticks from the patagonian region of Argentina. Acta Trop. 2016 162:218-21.

69. Saracho-Bottero MN, Tarragona EL, Sebastian PS, et al. Ticks infesting cattle and humans in the yungas biogeographic province of Argentina, with notes on the presence of tick-borne bacteria. Exp Appl Acarol. 2018;74:107-16.

70. Dall'Agnol B, Michel T, Weck B, et al. Borrelia burgdorferi sensu lato in Ixodes longiscutatus ticks from Brazilian pampa. Ticks Tick Borne Dis. 2017;8:928-32. 